Kong. Res. J. 4(1) : 114-120, 2017

ISSN 2349-2694

Kongunadu Arts and Science College, Coimbatore.

\title{
DOCUMENTATION OF ABORIGINAL TRADITIONAL KNOWLEDGE AND INHERENT INDIGENOUS THERAPEUTIC PLANTS OF COIMBATORE DISTRICT, TAMIL NADU, INDIA
}

\author{
Saradha, $\mathbf{M}^{1 *}$., P. Samydurai ${ }^{2}$, and G. Divya Bharathi ${ }^{1}$ \\ ${ }^{1}$ Department of Botany, Nirmala College for Women (Autonomous), Coimbatore-641 018. \\ ${ }^{2}$ Department of Botany, Bharathiar University, Coimbatore - 641045. \\ *E.mail: saradha.bio@gmail.com
}

\section{ABSTRACT}

The aim of the study was to investigate the medicinal plants used as therapeutic, nutritive and food additives which are consumed by the tribes of Coimbatore district, Tamil Nadu, India. The information was gathered from the local tribal community people, an aboriginal community who reside in the foothills, around the Coimbatore district. Several field visited to the tribal inhabitant areas to collect data on medicinal and aromatic plants commonly used by them. The observations collected during field visits were put to group discussion. The medicinal plants were identified, photographed and sample specimens were collected for preparation of herbarium. The results of the study have been documented that 47 plants belonging to 24 families and 38 genera used to treat wound healing, diabetics, jaundice, skin diseases, gastro intestinal disorders, ulcer, fever, cold, cough, bronchitis, ring worm, snake bites, burns healing, eye diseases, swelling, rheumatism, cosmetics and also used for malnutrition.

Keywords: Ethnobotanical knowledge, indigenous, therapeutic plants.

\section{INTRODUCTION}

Since time immemorial man has used various parts of the plants in the treatment and prevention from many diseases (Chah et al., 2006). The ethnomedicinal systems and herbal medicines are therapeutic agents in addressing health problems of traditional communities. Historically all the medicinal preparations were derived from plant parts having more complex of crude mixtures, which are active against a variety of diseases (Ayyanar and Ignacimuthu, 2009). This knowledge and wisdom includes healing traditions which have helped long for indigenous communities to maintain their personal health and wellness (Buenz, 2005). The medicinally important plants were identified to be used by ethnic people to cure various ailments such as diabetes, dysentery, fever, headache, rheumatism, snake bite, cough and some as food and food additives (Samydurai et al., 2012).

Plants used by the tribal people for treating rheumatism (Ayyanar and Ignacimuthu, 2005). Most of the tribes having traditional knowledge on medicinal plants that are used for primary health problems such as cough, cold, fever, headache, poisonous bites and some other simple diseases (Sutha et al., 2010). Certain wild tubers, root types, green leaves, flowers, unripe as well as ripe fruits, grains and legumes including tribal pulses are consumed by different tribal sects (Jain, 1981;
Maikhuri et al., 2000). The tribal societies are closely associated with the forest ecosystem where they live in tradition and harmony (Kadavul and Dixit, 2009). Huge amount of medicinal plant species are used by ethnic people for the various skin diseases like eruptions, eczema, leucoderma, sores, cracks, cuts, boils, wounds, external tumors and body pain, swellings (Reddy et al., 2010) and these diseases curative plants derive their daily needs from various plants growing around them. The indigenous groups possess their own distinct culture, religious rites, food habit and a rich knowledge of traditional medicine (Anuradha et al., 1986; Harsha et al., 2002).

Even today globally, about $85 \%$ of the traditional medicines used for primary health care are derived from plants (Farnsworth, 1998). Humans have developed knowledge of using available plants to treat a number of ailments based on different medicinal systems such as Ayurveda, Unani and Siddha (Meena, 2009). In India it is reported that traditional healers used 2500 plant species among that 100 species of plants serve as regular source of medicine (Pei, 2001). During the last few decades there has been an increasing interest in the study of medicinal plants and their traditional use in different parts of the World (Lev, 2006). Nowadays the urbanization leads the fast vanishing of traditional knowledge on the use of plants by tribals, so urgent need to document the 
medicinal plant knowledge otherwise it will be lost (Arinathan et al., 2007). Recently, considerable attention has been paid to utilize eco and biofriendly plant based drugs for the prevention and cure of different human disease (Ganesan, 2008). In our present investigation enlightened many of the important medicinal plants, which are needed to be document for therapeutic utilization in future.

\section{METHODOLOGY}

Frequent field surveys were carried out in and around Coimbatore hilly regions during June 2015 - June 2016 in various seasons. The ethnobotanical data (local name, medicinal uses and mode of consumption) were collected through interviews and discussions among the tribal practitioners around the study area. The curative plants were identified based on local names, photographs and sample specimens were collected for the preparation of herbarium. The collected specimens were identified taxonomically using The Flora of Presidency of Madras (Gamble, 1935); The Flora of Tamil Nadu and Carnatic (Mathew, 1983) and the following references Nair and Henry 1983; Henry et al., 1987; Chandrabose and Nair, 1988; Gamble, 1996. Voucher specimens have been deposited in the form of herbarium, Department of Botany, Nirmala College for Women (Autonomous), Coimbatore, Tamil Nadu, India.

\subsection{Study area}

The tribal inhabitants are in the Coimbatore district which is part of Southern Western Ghats of Coimbatore district. The following areas of northwest fields of Boluvampatty Range, Palamalai, Anaikatty, Maruthamalai and southwest regions of Siruvani and Anaimalai hills. Irula tribes are still using plants for their livelihood by consuming whole plants, leaves, roots, rhizomes, and tubers. They are also occupied in seasonal collection of honey, bee wax, fire woods and some minor forest products.

\section{RESULTS}

Coimbatore mountainous region have a variety of medicinal plants which are used by the Irula tribals for their primary healthcare and food security. The survey of 47 ethnic community curative plants species belongs to 38 genera and 24 families reported to be employed in the treatment of various skin diseases, wound healing, injuries like cuts, burns, bruises, sores, leprosy, itching, stimulants, carminatives and expectorants. The plants like Acalypha indica, Aloe vera, Calotropis gigantea, Cleome viscosa, Euphorbia hirta, Morinda citrifolia, Pongamia pinnata and Vitex negundo are commonly used by them.

Table 1. The enumeration of curative plant species used by the tribal community of Coimbatore district, with their family, local name, part used and medicinal uses.

\begin{tabular}{|c|c|c|c|c|c|c|}
\hline $\begin{array}{l}\text { S. } \\
\text { No. }\end{array}$ & Botanical name & Local name & Habit & Family & Part Used & $\begin{array}{c}\text { Ethnomedicinal uses/mode of } \\
\text { consumption }\end{array}$ \\
\hline 1 & Acalypha indica L. & Kuppaimeni & Herb & Euphorbiaceae & $\begin{array}{l}\text { Whole } \\
\text { plant }\end{array}$ & $\begin{array}{l}\text { Itching, Skin diseases, Rheumatoid } \\
\text { arthritis and scabies. }\end{array}$ \\
\hline 2 & $\begin{array}{l}\text { Allmania nodiflora } \\
\text { (L.) wt }\end{array}$ & Thoikeerai & Herb & Amaranthaceae & leaves & Leafy vegetable \\
\hline 3 & $\begin{array}{l}\text { Aloe vera (L.) } \\
\text { Burm.f }\end{array}$ & Sotru katrallai & Herb & Liliaceae & $\begin{array}{l}\text { Whole } \\
\text { plant }\end{array}$ & $\begin{array}{l}\text { Amenorrhea, wounds, ulcers, burns, } \\
\text { colic, hepatitis, skin diseases, } \\
\text { constipation, tumor, malignancy, low } \\
\text { back pain, edema, arthritis and } \\
\text { general debility. }\end{array}$ \\
\hline 4 & $\begin{array}{l}\text { Alternenthera } \\
\text { paronychioides A. } \\
\text { St.-Hil. }\end{array}$ & Ponnanganni & Herb & Amaranthaceae & Leaf & Leafy vegetable \\
\hline 5 & $\begin{array}{l}\text { Alternenthera } \\
\text { sessils L. DC }\end{array}$ & Ponnanganni & Herb & Amaranthaceae & Leaf & $\begin{array}{l}\text { Gastrointestinal disorder, improve } \\
\text { the male sexual potency. The weed is } \\
\text { sometimes used topically to treat } \\
\text { acne and eaten as vegetables. }\end{array}$ \\
\hline 6 & $\begin{array}{l}\text { Andrographis } \\
\text { paniculata Wall ex } \\
\text { Nees }\end{array}$ & Nilavempu & Herb & Acanthaceae & $\begin{array}{l}\text { Whole } \\
\text { plant }\end{array}$ & $\begin{array}{l}\text { Bitter tonic and febrifuge, blood } \\
\text { purifier, cure for torpid liver and } \\
\text { jaundice and diabetic. }\end{array}$ \\
\hline 7 & $\begin{array}{l}\text { Anisomeles indica } \\
\text { L. Kuntze }\end{array}$ & Peimeratti & $\begin{array}{l}\text { Woody } \\
\text { shrub }\end{array}$ & Lamiaceae & $\begin{array}{l}\text { Whole } \\
\text { plant }\end{array}$ & $\begin{array}{l}\text { Analgesic, anti-inflammatory, skin } \\
\text { problems and snake bite. }\end{array}$ \\
\hline 8 & $\begin{array}{l}\text { Aristolochia indica } \\
\text { L. }\end{array}$ & Aaduthinnapalai & Climber & Aristolochiaceae & Leaf & $\begin{array}{l}\text { Poison bite, skin diseases, intestinal } \\
\text { worms, colic, arthritis and ulcers. }\end{array}$ \\
\hline 9 & $\begin{array}{l}\text { Azadirachta indica } \\
\text { A. Juss. }\end{array}$ & Vembu & Tree & Meliaceae & $\begin{array}{l}\text { Bark, } \\
\text { leaves, } \\
\text { flower and }\end{array}$ & $\begin{array}{l}\text { Skin diseases, eczema, fever, wound, } \\
\text { ulcer, burning sensation, tumor, } \\
\text { worms, cough, diabetes, }\end{array}$ \\
\hline
\end{tabular}


10 Calotropis gigantea Yeruku
R.Br.

11 Canavalia virosa Thamatta

(Roxb.)

12 Centella asiatica Vallarai

(L.) Urban.

13 Capparis zeylanica Adondai, atontai

$\mathrm{L}$.

14 Caralluma

adscendens (Roxb.)

R.Br.

$15 \quad$ Caralluma

fimbriata (Roxb.)

R.Br.

16 Cardiospermum

halicacabum $\mathrm{L}$.

17 Cassia tora $\mathrm{L}$.

$18 \quad$ Cassia occidentalis L.

Ceropegia juncea Roxb

21

Cissus

quadrangularis (L.)

Wall. ex Wight

22

Cleome viscosa $\mathrm{L}$.

Naaikkadugu,

Kattu kadugu

23

Coccinia grandis
(L.) Voigt

24

Decalepis

hamiltonii Wight

and Arn.

25 Digera muricata

(L.) Mart

26 Dioscorea alata L.

27 Dioscorea oppositifolia L.

28

Eclipta prostrata L.

Kovai keerai

Mahali kizhangu

Thoikeerai

Vetrilaikodi

kizhangu

Kavala-kodi

Mangal

karisilakanni

29

Euphorbia hirta L.

Ammani

paccharichi

30 Hemidesmus

indicus (L.) R.Br

31

Leucas

Spreng

aspera

Nannari

32

Morinda citrifolia

L.

33 Mucun

(L.) DC.

Thumbai

Nunamaram
Perennial Asclepiadaceae

shrub

Climber

Herb

Climbing

Thorny

shrub

Succulent

herb

Succulent

herb

Climber

Herb

Herb

Herb

Climber

Climber

Annual

herb

Climber

Climber

Herb

Climber

Climber

Herb

Herb

Climber

Herb

Tree

Climber
Asclepiadaceae

Apiaceae

Capparidaceae

Asclepiadaceae

plant

Asclepiadaceae

Asclepiadaceae

Sapindaceae

Fabaceae

Fabaceae

Amaranthaceae

plant

Vitaceae

Capparidaceae

Cucurbitaceae

Asclepiadaceae

Amaranthaceae

Dioscoreaceae

Dioscoreaceae

Asteraceae

Euphorbiaceae

Asclepiadaceae

seeds.

Root, Latex,

Flower and

Leaves

Fruit

Whole

plant

Fruit

Whole

plant

Whole

plant

Whole

plant

Seeds and

leaves

Root, seed and leaves.

Leaves

plant

Young leaf

Whole

plant

Leaf an

Fruit

Tuber

Leaf

Tuber

Tuber

Whole

plant

Whole

plant

Root

Lamiaceae

Rubiaceae

Fabaceae

Leaves,

Flowers

Fruit Pulp

and bark

Fruits, inflammation and rheumatoid arthritis.

Skin diseases, joint inflammations, snake poison, asthma, chest infections, rabies and its strong purgative drug.

Young fruits used as vegetables.

Health tonic and memory enhance

Sedative, stomach, anticholerin, diuretic

febrifuge, piles and swellings.

Antidiabetic, chronic illnesses and diet control.

Antidiabetic, obesity, appetizer and heart disease.

Constipation, fever, amenorrhea, low back pain and rheumatism.

Leprosy, ringworm, itching,snake bite and arthritis

Cough, bronchitis, allergy, asthma, fever constipation, diabetes, skin diseases, wounds and ulcers.

Leafy vegetable used as antidiarrhoeal, antibacterial and cooling.

Tranquilizer, hypotensive, hepatoprotective, antiulcer, and antipyretic.

Piles, osteoporosis, anorexia and fracture.

Intestinal worms, colic, stomach upset, cardio myopathy, diarrhea, fever and dyspepsia.

Constipation, burning sensation, leucorrhea, skin disease, fever, asthma, cough and jaundice.

Appetizer, blood purifier, diabetics, indigestion and health tonic.

Astringent, laxative, diuretic and urinary discharges.

Tuber used as stable food and nutritive.

Tuber used as stable food, diarrhea, dysentery, indigestion and urinary discharges.

Reduce pain, promote hair growth, stimulate the functions of liver and ulcers.

Asthma, skin diseases, fever, cough and dysentry.

Health tonic, diabetic, bronchitis, asthma, diarrhea, dysentery, arthritis, fever and general debility.

Leaves,
Inflammation, worm infestation, arthritis, cough, amenorrhea, intermittent fever and ulcer.

Cough, fever, diabetes, swelling, analgesic, diarrhea and diuretic. Parkinsonism, kidney diseases,
Constipation, impotency, 


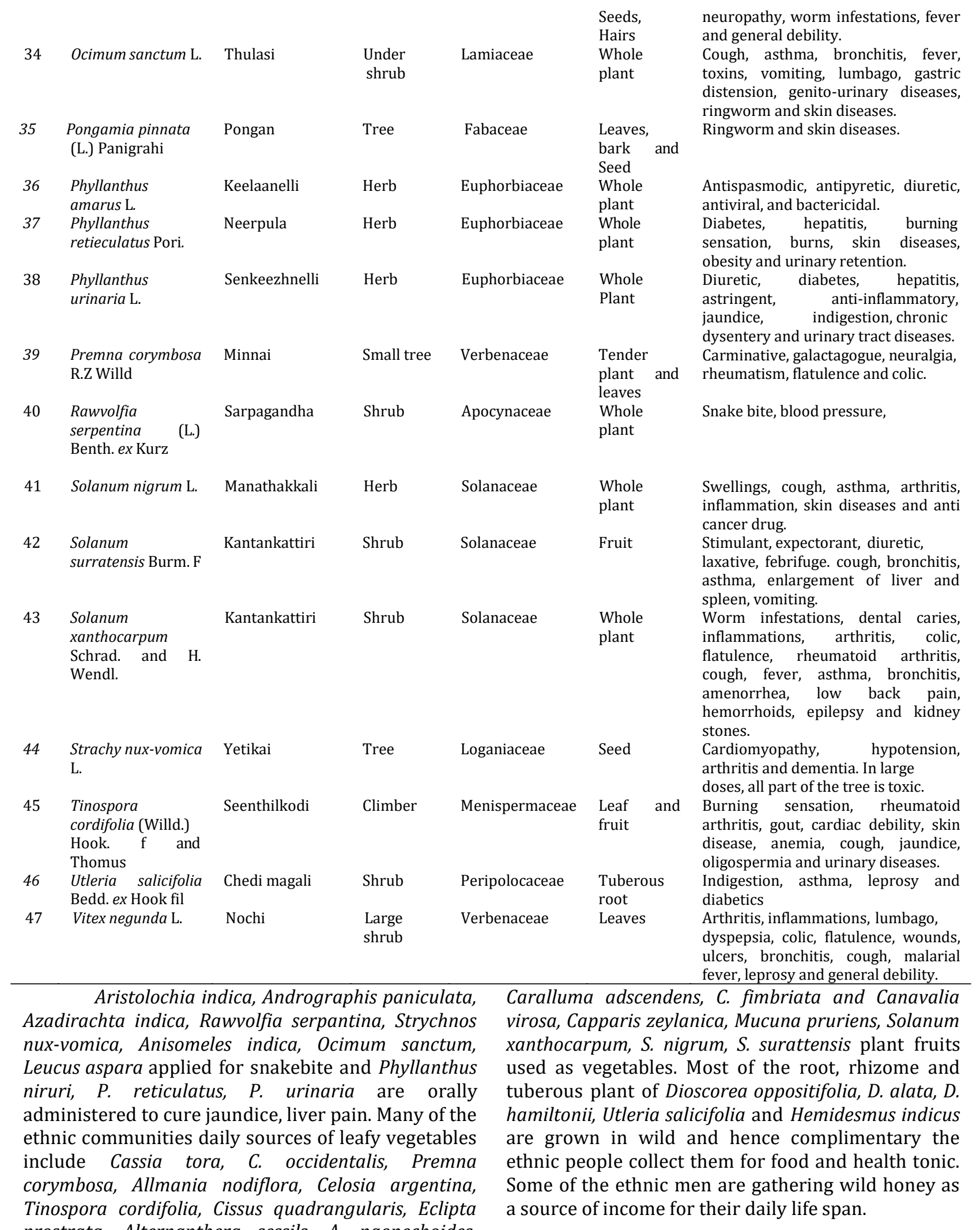
prostrata, Alternanthera sessils, A. paonechoides,
Cardiospermum halicacabum, Cocacinia grandis,
Digera muricata, Centella asiatica, Ceropegia junceae, 
age, physical status and health conditions of tribal children. Before starting the treatment, the condition of the patient is observed deeply and then the prepared medicines are given to treat diseases. For topical, the most important methods used are direct application of the plant paste and mostly deals with ailments like skin diseases, wounds, poison bites, rheumatism, body pain and headache. Some of the ailments are treated by internal consumption as well as therapeutic application such as poison bite, rheumatic and body pain. In some of the sickness such as cold, cough, fever and headache inhalation is also involved. Tribal practitioners are using specific plant parts and definite dosages for the treatment of diseases.

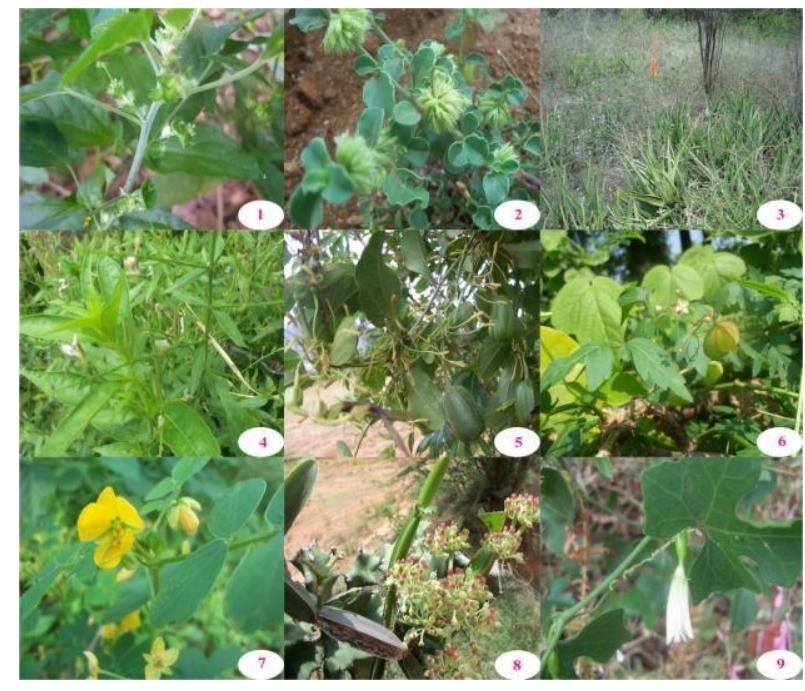

Figs. 1-9. Inherent indigenous therapeutic plants of Western Ghats part of Coimbatore region. 1. Acalypha indica 2. Allmania nodiflora 3. Aloe vera 4.Andrographis paniculata 5.Aristolochia indica 6. Cardiospermum halicacabum 7. Cassia occidentalis 8. Cissus quadrangularis 9. Coccinia grandis.

\section{DISCUSSION}

In the present investigation 47 plant species were found to be used by the tribes of traditional medicinal system for the treatment of various diseases like skin diseases, wound healing, stimulant and expectorant.The different parts of the plant such as leaves, fruits, roots and bark are used as food and medicine. Paliyar tribes inhabiting the Anaimalai hills are used 55 species of plants for the treatment of various ailments, food, cultural, traditional and religious ceremonies (Sivakumar et al., 2003). Muthukumarasamy et al. (2003) reported that Paliyar tribes using 21 medicinal plants to get relief from gastro-intestinal disorders and the information was collected from the elderly and experienced persons practicing indigenous medicines. Rajendran et al. (2003) surveyed the tribes inhabiting area, to collect the information on ethnomedicinal plants used by them for their primary healthcare and the survey enumerated 43 species of plants with multiple ethnomedicinal properties.

Local traditional healthcare practitioners used it to treat various ailments such as vomiting and dysentery (Ravishankar and Henry, 1992). Aboriginal community tribes mainly used 13 Phyllanthus species in different diseases like anemia, diabetes, malaria, tuberculosis, whooping cough, diuretic, jaundice, HIV, asthma, purgative, fever and headache (Lakshmi Narasimhudu and Venkata Raju, 2013). Rural people also used medicinal plants as traditional medicine for scabies, diarrhoea, urinary trouble, kidney stone, constipation and arthritis (Desale et al., 2013). Recent reports of ethnomedicinal knowledge of traditionally used edible leaves, seeds, roots and bark are used for primary healthcare problem such as fever, cough, headache, body pain and also as an energy tonic (Solomon Raju and Venkata Ramana, 2011; Samydurai et al., 2012; Alagesaboopathi, 2014). Most of the medicinal plants are used by the herbal practitioner to treat common ailments for diuretic, snake bites, jaundice, piles, ulcer, swellings, weight loss, diabetics, cough and cold, body pain, diarrhea as anti-inflammatory and anti-cancerous. The traditional knowledge of ethnomedicinal plants and their therapeutic practices among Irula tribals may be helpful to improve the future pharmaceutical applications (Kalaiselvan and Gopalan, 2014). The study reveals that the herbs collected from forests and farmlands are used to cure the common ailments used medicinal plants by aboriginal people have been the custodians of forests and have sustained healthy life-styles in an eco-friendly manner (Pradheeps et al., 2015).

\section{CONCLUSION}

During the interviews, discussions among the ethnic communities, traditional healers and local people around the Coimbatore district of Tamilnadu, revealed that the area is rich in medicinal plant diversity and the most popular mode of preparation of drugs including decoction, infusion, paste, juice, powder and also in the form of vegetables. This study reveals that ethnic community people and traditional healers generally depend on the forest resources for medicinal plants to treat various ailments. 


\section{ACKNOWLEDGEMENT}

Vellaiyan P, a local Herbalist and the people of the villages Boluvampatty, Palamalai, Anaikatty, Maruthamalai, Poondi and southwest regions of Siruvani and Anaimalai hills are thankfully acknowledged for heartfelt their help for collecting indigenous medicinal plants and other ethnobotanical information.

\section{REFERENCES}

Alagesaboopathi, C. (2014). Medicinal Plants Used by Tribal and Non-Tribal People of Dharmapuri District, Tamil Nadu, India. Int. J. Curr. Res. Biosci. Plant Biol 1(2): 64-73.

Anuradha, U., Kumbhojkar, M.S. and V.D. Vartak, (1986). Observations on wild plants used in folk medicine in the rural areas of the Kolhapur district. Ancient Sci. Life 6: 119-121.

Arinathan, V., V.R. Mohan, A. John De Britto and C. Murugan, (2007). Wild edibles used by Palliyars of the Western Ghats, Tamil Nadu. Indian J. Trad. Know 6(1): 163-168.

Ayyanar, M. and S. Ignacimuthu, (2005). Medicinal plants used by the tribals of Tirunelveli hills, Tamil Nadu to treat poisonous bites and skin diseases. Indian J. Trad. Know 4(3): 229-236

Ayyanar, M. and S. Ignacimuthu (2009). Herbal medicines for wound healing among tribal people in Southern India: Ethnobotanical and Scientific evidences. Int. J. Appl. Res. Nat. Prod 2(3): 29-42.

Buenz, E. (2005). Country development does not presuppose the loss of forest resources for traditional medicine use. J Ethnopharmacol 100: 118-123.

Chah, K.F., Eze, C.A., Emuelosi, C.E. and C.O. Esimone, (2006). Antibacterial and wound healing properties of methanolic extracts of some Nigerian medicinal plants. J. Ethnopharmacol 104: $164-167$.

Chandrabose, M. and N.C. Nair, (1988). Flora of Coimbatore. Bishen Singh Mahendra Pal Singh, Dehra Dun.

Dasale, M.K., Bhamare, P.B., Sawant, P.S., Patil, S.R. and S.Y. Kamble, (2013). Medicinal plants used by the rural people of Taluka Purandhar, district Pune, Maharashtra. Indian J. Trad. Know 12: 334-338.

Farnsworth, J.D. (1988). Screening plants for new medicines. In: Wilson E.O. (eds.) Biodiversity. National Academy Press, Washington, DC, pp. 83-97.
Gamble, J.S. (1935). The Flora of the Presidency of Madras. Adlard and son, LTD, London.

Gamble, J.S. (1996). The flora of the Presidency of Madras (Adland and Son Ltd, London).

Ganesan, S. (2008). Traditional oral care medicinal plant survey of Tamil Nadu. Natural Product Radia. 7: 166-172.

Harsha, V.H., Hebbar, S.S., Hegde, G.R. and V. Shripathi, (2002). Ethnomedical knowledge of plants used by Kunabi Tribe of Karnataka in India. Fitoterapia 73: 281-287.

Henry, A.N., Chithra, V. and N.P. Balakrishnan, (1987). Flora of Tamilnadu; India: Series - I. Analysis. Vol-II. Botanical Survey of India, Coimbatore.

Jain, S.K. (1981). Observations on Ethnobotany of the tribal of Central India. In: Jain, S.K. (eds.), Glimpses of Indian Ethnobotany. (Oxford and IBH, New Delhi), 193-198.

Kadavul, K. and A.K. Dixit, (2009). Ethnomedicinal studies of the woody species of Kalrayan and Shervarayan hills, Eastern Ghats, Tamilnadu, India. Indian J. Trad. Know 8: 592-597.

Kalaiselvan, M. and R. Gopalan, (2014). Ethnobotanical studies on selected wild medicinal plants used by Irula tribes of Bolampatty Valley, Nilgiri Biosphere Reserve (NBR), Southern Western Ghats, India. Asian J. Pharm. Clin. Res 7(1): 22-26.

Lakshmi Narasimhudu and Venkata Raju (2013). Medicobotanical properties of Phyllanthus species (Euphobiaceae) used by the aboriginal adivasis of Eastern Ghats, Andra Pradesh. Indian J. Trad. Know 12(2): 326-333.

Lev, E. (2006). Ethno-diversity within current ethnopharmacology as part of Israeli traditional medicine-A review. J Ethnobiol. Ethnomed 2: 4.

Maikhuri, R.K., Nautiyal, S., Rao, K.S., Chandrasekhar, K., Gavali, R and K.G. Saxena, (2000). Analysis and resolution of protected area-people conflicts in Nanda Devi Biosphere Reserve. Envir. Conservation 27: 43-53.

Matthew, K.M. (1983). The Flora of the Tamil Nadu Carnatic. The Rapinat Herbarium, St Joseph's College, Tiruchirapalli, India.

Meena AK, Parveen Bansal, Sanjiv Kumar (2009). Plants-herbal wealth as a potential source of ayurvedic drugs. Asian J Trad Med 4(4): 152170. 
Muthukumarasamy, S., Mohan, V.R., Kumaresan, S. and V. Chelladurai, (2003). Herbal medicinal plants used by Paliyars to obtain reliegf from gastro-intestinal complaints. J. Econo. Taxo. Bot. 27: 711-714.

Nair, N.C. and A.N. Henry, (1983). Flora of Tamilnadu India: Series-I. Analysis. Vol. I. Botanical Survey of India, Coimbatore.

Pei, J.S. (2001). Ethnobotanical approaches of traditional medicinal studies: Some experiences from Asia. Pharma. Biol 39: 74-79.

Pradheeps, M., Chella Perumal, A. and G. Poyyamoli, (2015). Traditional practices of native communities and their ethnobotanical knowledge: A trivia in Wayanad, India. J. Ethnobiol. Trad. Med. Photon 124: 993-100.

Rajendran, S.M., Agarwal, S.C. and V. Sundaresan, (2003). Lesser known Ethnomedicinal Plants of the Ayyakarkoil Forest Province of Southwestern Ghats, Tamil Nadu, India. J. Her. Spic. Med. Plants 10: 103-112.

Ravishankar, T. and A.N. Henry, (1992). Ethnobotany of Adilabad district, Andhra Pradesh, India. Ethnobotany 4: 45 -52.

Reddy, K.N., Trimurthulu, G. and C.S. Reddy, (2010). Plants used by the ethnic people of Krishna district, Andhra Pradesh. Indian J. Trad. Know 9(2): 313-317.
Samydurai, P., Jagathes Kumar, S., Aravindhan, V. and V. Thangapandian, (2012). Survey of wild aromatic ethnomedicinal plants of velliangiri hills in the Southern Western Ghats of Tamilnadu, India. Inter. J. Medi and Arom Plants 2(2): 229-234.

Samydurai, P., Thangapandian, V. and V. Aravindhan (2012). Wild habits of Kolli Hills being staple food of inhabitant tribes of Eastern Ghats, Tamil Nadu, India. Indian J. of Nat Prod Res 3: 432437.

Sivakumar, A., Subramanian, M.S., Karunakaran, M. and A. Burkanudeen, (2003). Ethnobotany of Poliyars of Anaimalai hills, Tamil Nadu. J. Econ. Taxon. Bot 27: 679-685.

Solomon Raju, A.J. and K. Venkata Ramana (2011). Traditional preparation of a health drink Nannari Sharbat from the root extract of Decalepis hamiltonii Wight and Arn. Indian J Nat Prod Res 2(1): 121-124.

Sutha, S., Mohan, V.R., Kumaresan, S., Murugan, C. and T. Athiperumalsami, (2010). Ethnomedicinal plants used by the tribals of Kalakad-Mundanthurai Tiger Reserve (KMTR), Western Ghats, Tamil Nadu for the treatment of rheumatism. Indian J Trad Know 9(3): 502-509. 